\title{
Purification and Immunochemical Characterization of Malate Synthase from Euglena gracilis
}

\author{
By ELAINE WOODCOCK and MICHAEL J. MERRETT \\ Postgraduate School of Biological Sciences, University of Bradford, Bradford, Yorks. BD7 1DP, U.K.
}

(Received 8 November 1977)

\begin{abstract}
Malate synthase (EC 4.1.3.2) from dark-grown Euglena gracilis was purified to homogeneity by the criterion of polyacrylamide-gel electrophoresis. The enzyme was released from acetate-grown cells by treatment with ultrasonic waves and purified from broken-cell suspensions by high-speed centrifugation and $\left(\mathrm{NH}_{4}\right)_{2} \mathrm{SO}_{4}$ fractionation, followed by gel-filtration on Sepharose 6B. The final enzyme preparation was purified 190-fold compared with the crude extract. The mol.wt. of the enzyme was about 350000 as determined by gel filtration on Sepharose 6B. Treatment with sodium dodecyl sulphate and urea dissociated the enzyme into subunits of mol.wt. 175000. The pH optimum for the enzyme was 8.0 and the $K_{\mathrm{m}}$ values for glyoxylate and acetyl-CoA were 50 and $80 \mu \mathrm{M}$ respectively. Antibodies raised to the purified enzyme were shown to be monospecific by radiochemical immunoassay. Euglena anti-(malate synthase) tested on Ouchterlony double-diffusion gels gave a sharp precipitation band against acetate-grown Escherichia coli, but no immunological correspondence was observed with acetate-grown Chlorella fusca, Zea mays (maize) scutella or purified malate synthase from Ricinus communis.
\end{abstract}

Malate synthase (EC 4.1.3.2), the second key enzyme of the glyoxylate cycle, catalyses the condensation of acetyl-CoA with glyoxylate to form malate (Wong \& Ajl, 1956). This enzyme is widely distributed in micro-organisms, and in divisionsynchronized cultures of Euglena gracilis the rate of malate synthase induction is constant for much of the cell cycle, but doubles in a single step during the period of DNA replication (Woodward \& Merrett, 1975). To determine the expression of the structural gene for malate synthase during the cell cycle of Euglena it was necessary to purify and characterize this enzyme immunochemically. Moreover, although malate synthase is present in acetategrown bacteria (Kornberg, 1959; Falmagre et al., 1965), protozoa (Hogg \& Kornberg, 1963), yeast (Dixon et al., 1960; Duntze et al., 1969) and algae (Syrett et al., 1963; Harrop \& Kornberg, 1966) the quaternary structure of the enzyme from microorganisms has not been investigated. In the present paper we report on the quaternary structure of Euglena malate synthase and its immunological relationship to the enzyme from other organisms.

\section{Materials and Methods}

\section{Growth of cells}

Euglena gracilis Klebs strain $\mathrm{z}$ was grown at $25^{\circ} \mathrm{C}$ in the dark in the medium of Cramer \& Myers (1952)

Abbreviation used: SDS, sodium dodecyl sulphate. supplemented with $35 \mathrm{~mm}$-sodium acetate at $\mathrm{pH} 6.7$. The initial inoculum added to 24 litres of medium was $500 \mathrm{ml}$ of an exponential-phase culture growing photoautotrophically (Collins \& Merrett, 1975a) containing approx. $10^{5}$ cells $/ \mathrm{ml}$.

Escherichia coli (N.C.T.C. 8007) was grown in the medium of Dixon et al. (1960).

Chlorella fusca strain 211/8P (Cambridge Culture Collection) was grown as described by Goulding \& Merrett (1966).

Zea mays (maize) seeds were soaked overnight in running tap water, then germinated in moist vermiculite at $25^{\circ} \mathrm{C}$ and used after 4 days germination.

\section{Labelling Euglena proteins with ${ }^{35} \mathrm{~S}$}

A photoautotrophically growing Euglena culture in mid-exponential phase was harvested aseptically and resuspended in $50 \mathrm{ml}$ of Cramer \& Myers (1952) medium to give a density of $5 \times 10^{4}$ cells $/ \mathrm{ml}$. Sterile sodium acetate was added to give a final concentration of $35 \mathrm{~mm}$ and the culture incubated in the dark at $25^{\circ} \mathrm{C}$ for $4 \mathrm{~h}$. A pulse of $50 \mu \mathrm{Ci}$ of $\mathrm{L}-\left[{ }^{35} \mathrm{~S}\right]-$ methionine $(555 \mathrm{Ci} / \mathrm{mmol})$ was added to the culture, and after $2 \mathrm{~h}$ the culture was harvested by centrifuging for $10 \mathrm{~min}$ at $4000 \mathrm{~g}$.

\section{Preparation of cell extracts}

Cultures of Euglena or E. coli were harvested by centrifuging for $10 \mathrm{~min}$ at $4000 \mathrm{~g}$, washed once and 
resuspended in extraction buffer $(50 \mathrm{~mm}-\mathrm{Tris} / \mathrm{HCl}$, pH 7.5, containing $10 \mathrm{mM}-\mathrm{MgCl}_{2}$ and $1 \mathrm{~mm}$-dithiothreitol) and the cells disrupted at $0^{\circ} \mathrm{C}$ by three $15 \mathrm{~s}$ bursts of ultrasonic waves, with $1 \mathrm{~min}$ intervals between the bursts (MSE ultrasonic disintegrator, 1.5A). Chlorella cells were suspended in the same buffer but disrupted by passage through a French Pressure cell at $82.7 \mathrm{MPa}\left(12000 \mathrm{lb} / \mathrm{in}^{2}\right)$. Seeds of $\mathrm{Zea}$ mays were ground with sand in the extraction buffer. Broken-cell suspensions were centrifuged for $30 \mathrm{~min}$ at $4^{\circ} \mathrm{C}$ at $100000 \mathrm{~g}_{\mathrm{av}}$. in a 40.3 rotor (Beckman L5-40 ultracentrifuge) and the supernatant was used for enzyme assays and immunological studies.

\section{Purification of malate synthase from Euglena gracilis}

Cells were harvested by centrifugation in an MSE continuous-action rotor, weighed, washed and resuspended in extraction buffer to give $0.5 \mathrm{~g}$ fresh wt. of cells $/ \mathrm{ml}$ of buffer. Cells were disrupted by passage through a chilled French pressure cell at $82.7 \mathrm{MPa}\left(12000 \mathrm{lb} / \mathrm{in}^{2}\right)$ and the broken-cell suspension was centrifuged at $4000 \mathrm{~g}$ for $10 \mathrm{~min}$ at $4^{\circ} \mathrm{C}$ to remove intact cells. The resultant pellet was reextracted with half the original volume of extraction buffer, centrifuged again, and the supernatants were combined and adjusted to pH7.5 when necessary. The extract was then centrifuged at $53000 g_{\text {av. }}$ at $4^{\circ} \mathrm{C}$ for $16 \mathrm{~h}$ in an SW27 rotor (Beckman L5-40 ultracentrifuge).

Solid $\left(\mathrm{NH}_{4}\right)_{2} \mathrm{SO}_{4}$ was added slowly with stirring to the high-speed supernatant at $0^{\circ} \mathrm{C}$ to give $30 \%$ saturation (Dawson et al., 1969). During the addition of $\left(\mathrm{NH}_{4}\right)_{2} \mathrm{SO}_{4}$ the $\mathrm{pH}$ was measured with a glass electrode and maintained at 7.5 by the addition of $1 \mathrm{M}-\mathrm{NaOH}$ or $1 \mathrm{M}-\mathrm{HCl}$ as necessary. The solution was left without stirring for $30 \mathrm{~min}$, then centrifuged at $18000 \mathrm{~g}$ for $20 \mathrm{~min}$ and the precipitate retained for enzyme assay. More $\left(\mathrm{NH}_{4}\right)_{2} \mathrm{SO}_{4}$ was added to the supernatant to give $40 \%$ saturation and the above procedure repeated. Finally, more $\left(\mathrm{NH}_{4}\right)_{2} \mathrm{SO}_{4}$ was added to the supernatant to give $50 \%$ saturation, and after standing for $30 \mathrm{~min}$, the precipitate was collected by centrifugation as above and dissolved in $10 \mathrm{ml}$ of extraction buffer. This enzyme preparation was fractionated at $4^{\circ} \mathrm{C}$ on a column $(2 \mathrm{~cm} \times 100 \mathrm{~cm})$ of Sepharose 6B which had previously been equilibrated with extraction buffer. The same buffer was used to elute the sample and $3 \mathrm{ml}$ fractions were collected.

\section{Enzyme purity and molecular weight}

Fractions from the Sepharose 6B column showing peak malate synthase activity were tested for purity by SDS/polyacrylamide-gel electrophoresis by the method of Weber \& Osborn (1969).
Samples containing $30 \mu \mathrm{g}$ of protein were made $1 \%(\mathrm{w} / \mathrm{v})$ in SDS, $1 \%(\mathrm{w} / \mathrm{v})$ in $\beta$-mercaptoethanol and $8 \mathrm{M}$ in urea, then heated at $90^{\circ} \mathrm{C}$ for $3 \mathrm{~min}$ to dissociate the enzyme into subunits. After cooling to $20^{\circ} \mathrm{C}$ the samples were applied to $5 \%(\mathrm{w} / \mathrm{v})$ polyacrylamide gels and electrophoresis was carried out at a constant current of $8 \mathrm{~mA} / \mathrm{gel}$.

Gel electrophoresis for the non-dissociated enzyme was the same as above, except that SDS was omitted from the gel and reservoir buffer and the protein was not pretreated with $1 \%$ SDS and $8 \mathrm{M}$-urea. Gels were stained for protein with Coomassie Blue.

The molecular weight of the whole enzyme was determined on a column $(2 \mathrm{~cm} \times 100 \mathrm{~cm})$ of Sepharose 6B by conventional methods (Andrews, 1965) with Euglena ribulose 1,5-bisphosphate carboxylase (mol.wt. 520000), catalase (mol.wt. 240000), yeast alcohol dehydrogenase (mol.wt. 150000), bovine serum albumin (mol.wt. 68000) and cytochrome $c$ (mol.wt. 12400) as the standards.

The molecular weight of the subunits of the dissociated enzyme was determined by SDS/polyacrylamide-gel electrophoresis on $5 \%$ gels (Weber \& Osborn, 1969). Soya-bean trypsin inhibitor (mol.wt. 21500), bovine serum albumin (mol.wt. 68000), $E$. coli RNA polymerase $\alpha$-subunit (mol.wt. 39000), $\beta$-subunit (mol.wt. 155000) and $\beta^{\prime}$-subunit (mol.wt. 165000 ) were used as standard proteins.

\section{Stain for glycoprotein}

Gels of purified malate synthase run as above were stained for glycoprotein with the Schiff reagent by the method of Segrest \& Jackson (1972).

\section{Enzyme assays}

Malate synthase was assayed by the method of Cook (1970). The reaction mixture contained, in a final volume of $3.0 \mathrm{ml}, 200 \mu \mathrm{mol}$ of Tris $/ \mathrm{HCl}$ buffer, $\mathrm{pH} 8.0,20 \mu \mathrm{mol}$ of $\mathrm{MgCl}_{2}, 0.4 \mu \mathrm{mol}$ of acetyl-CoA, $1 \mu \mathrm{mol}$ of glyoxylate and $0.5 \mathrm{ml}$ of enzyme extract. The reaction was started by the addition of glyoxylate and the disappearance of acetyl-CoA followed at $232 \mathrm{~nm}$ on a Gilford recording spectrophotometer.

Citrate synthase (EC 4.1.3.7) was assayed by the method of Weitzman (1969); the increase in $A_{412}$ was followed after the addition of $0.1 \mu \mathrm{mol}$ of oxaloacetate to a cuvette containing $9.5 \mu \mathrm{mol}$ of Tris/ $\mathrm{HCl}$ buffer, pH8.0, $0.1 \mu \mathrm{mol}$ of 5,5'-dithiobis(2-nitrobenzoic acid), $0.15 \mu \mathrm{mol}$ of acetyl-CoA and cell extract to a total volume of $1 \mathrm{ml}$.

\section{Protein determination}

Protein was measured by the method of Lowry et al. (1951) by using a standard curve prepared for 
crystalline bovine albumin. In column-chromatography experiments the protein elution profile was monitored by recording the $\boldsymbol{A}_{\mathbf{2 8 0}}$.

\section{Preparation and partial purification of antiserum}

Peak fractions from the Sepharose 6B column that were homogeneous for malate synthase by the criterion of polyacrylamide-gel electrophoresis were dialysed against dry Sephadex G-25 at $4^{\circ} \mathrm{C}$ until the volume was decreased to approx. $0.7 \mathrm{ml}$. Complete Freund's adjuvant $(1 \mathrm{ml})$ was emulsified with $1 \mathrm{mg}$ of enzyme protein and injected intramuscularly into a New Zealand white rabbit. Injections were repeated at 3-week intervals until a total of four injections were given. Blood was collected by cardiac puncture 3 weeks after the last injection and allowed to clot overnight at $4^{\circ} \mathrm{C}$. The serum was collected by centrifugation at $40000 \mathrm{~g}$ for $15 \mathrm{~min}$ at $4^{\circ} \mathrm{C}$, then $\left(\mathrm{NH}_{4}\right)_{2} \mathrm{SO}_{4}$ was added to give $50 \%$ saturation. The precipitate was collected by centrifugation at $18000 \mathrm{~g}$ for $20 \mathrm{~min}$ at $4^{\circ} \mathrm{C}$ and redissolved in $20 \mathrm{~mm}$-sodium phosphate buffer, $\mathrm{pH} 7.0$, containing $0.15 \mathrm{M}-\mathrm{NaCl}$, so that the final volume was half the original serum volume. The immunoglobulin $\mathbf{G}$ preparation was dialysed overnight at $4^{\circ} \mathrm{C}$ against the same buffer before being divided into small batches and stored at $-20^{\circ} \mathrm{C}$.

\section{Quantitative precipitation reaction of the antiserum to malate synthase}

Quantitative precipitation reactions were carried out as described by Kabat \& Mayer (1961). Antiserum or control (preimmunization) serum $(0.1 \mathrm{ml})$ was incubated with purified malate synthase (up to $0.22 \mathrm{mg}$ of protein) in a volume of $0.6 \mathrm{ml}$ for $30 \mathrm{~min}$ at $37^{\circ} \mathrm{C}$, followed by storage at $4^{\circ} \mathrm{C}$ for $16 \mathrm{~h}$ to ensure complete precipitation. Immunoprecipitates were collected by centrifuging at $1500 \mathrm{~g}$ for $10 \mathrm{~min}$, washed three times with $3 \mathrm{ml}$ of $0.15 \mathrm{M}-\mathrm{NaCl}$, then dissolved in $2 \mathrm{ml}$ of $0.1 \mathrm{M}-\mathrm{NaOH}$ and the $A_{280}$ was measured or protein determined by the method of Lowry et al. (1951).

Residual enzyme activity was measured by incubating $50 \mu \mathrm{l}$ samples of purified malate synthase with increasing amounts of antiserum in a final volume of $150 \mu \mathrm{l}$ for $30 \mathrm{~min}$ at $37^{\circ} \mathrm{C}$, followed by $16 \mathrm{~h}$ at $4^{\circ} \mathrm{C}$. The mixture was centrifuged at $1500 \mathrm{~g}$ for $10 \mathrm{~min}$, and $50 \mu \mathrm{l}$ samples of the supernatants were used for enzyme assay.

\section{Analysis of malate synthase immunoprecipitate from Euglena cell extracts}

Cell extract $(200 \mu \mathrm{l})$ from the $\left[{ }^{35}\right.$ S]methioninelabelled cells was incubated with $100 \mu \mathrm{l}$ of anti(malate synthase) serum for $30 \mathrm{~min}$ at $37^{\circ} \mathrm{C}$, followed by $16 \mathrm{~h}$ at $4^{\circ} \mathrm{C}$. After centrifugation at $1500 \mathrm{~g}$ for $10 \mathrm{~min}$, the immunoprecipitate was washed three times with $3 \mathrm{ml}$ of $0.1 \mathrm{M}$-Tris/ $\mathrm{HCl}$ buffer, $\mathrm{pH} 7.5$, containing $10 \mathrm{~mm}-\mathrm{MgCl}_{2}, 50 \mathrm{~mm}-\mathrm{KCl}, 5 \mathrm{~mm}-\beta$-mercaptoethanol and $0.5 \%(\mathrm{w} / \mathrm{v})$ Triton $X-100$, and then again in the above buffer without Triton X-100.

The immunoprecipitate was dissolved in sample buffer [10mM-sodium phosphate, $\mathrm{pH} 7.2$, containing $1 \%(\mathrm{w} / \mathrm{v})$ SDS, $8 \mathrm{~m}$-urea and $1 \%$ (w/v) $\beta$-mercaptoethanol], heated at $90^{\circ} \mathrm{C}$ for $3 \mathrm{~min}$ and analysed on $5 \%$ SDS/polyacrylamide gels (Weber \& Osborn, 1969). Gels were stained for protein with Coomassie Blue, scanned at $600 \mathrm{~nm}$ with a Gilford Gel Scanner, frozen with powdered solid $\mathrm{CO}_{2}$, and cut into $1 \mathrm{~mm}$-thick slices with a Mickle gel slicer. Gel slices were dissolved in $200 \mu \mathrm{l}$ of $\mathrm{H}_{2} \mathrm{O}_{2}(30 \%)$ by heating at $70^{\circ} \mathrm{C}$ for $2 \mathrm{~h}$, then added to $5 \mathrm{ml}$ of Bray's (1960) solvent/scintillator and counted for radioactivity at $70 \%$ efficiency in a Packard Tri-Carb liquidscintillation counter.

\section{Immunodiffusion studies}

Antibody specificity was determined for anti(Euglena malate synthase) by the Ouchterlony (1968) double-diffusion technique on slides containing $0.8 \%(\mathrm{w} / \mathrm{v})$ agarose prepared in $0.1 \mathrm{M}$-sodium phosphate buffer (pH7.5). Precipitation bands were allowed to develop at $20^{\circ} \mathrm{C}$ for $48 \mathrm{~h}$. Control gels were run by using control (preimmunization) serum in place of anti-(malate synthase). Gels were stained for the presence of minor bands by flooding with $1.7 \%(\mathrm{w} / \mathrm{v}) \mathrm{NaCl}$ for $24 \mathrm{~h}$, soaking for $24 \mathrm{~h}$ in several changes of water, staining with Coomassie Blue, then destaining with aq. $5 \%(\mathrm{v} / \mathrm{v})$ methanol containing $7.5 \%(\mathrm{v} / \mathrm{v})$ acetic acid.

Cell extracts from Zea mays, Ricinus communis, E. coli, Chlorella fusca and phototrophic- and photoheterotrophic-grown Euglena gracilis were investigated by this method. All cell extracts contained at least $18 \mathrm{mg}$ of protein $/ \mathrm{ml}$.

\section{Other materials}

Dithiothreitol, acetyl-CoA, glyoxylic acid, $\beta$ mercaptoethanol and agarose were from Sigma (London) Chemical Co., London S.W.6, U.K. Sephadex G-25 and Sepharose 6B were from Pharmacia, Ealing, London W.5, U.K. Freund's complete adjuvant was from Difco Laboratories, Detroit, MI, U.S.A. L- ${ }^{35}$ S $]$ Methionine was from The Radiochemical Centre, Amersham, Bucks., U.K. Calibration proteins for SDS/polyacrylamidegel electrophoresis were from Boehringer-Mannheim, London W5 2TZ, U.K. All other reagents were from BDH Chemicals, Poole, Dorset, U.K., and were of the highest purity available. 
Table 1. Purification of malate synthase from dark-grown Euglena gracilis For details see the text.

\begin{tabular}{|c|c|c|c|c|c|c|}
\hline Step & $\begin{array}{l}\text { Protein } \\
(\mathrm{mg} / \mathrm{ml})\end{array}$ & $\begin{array}{l}\text { Total } \\
\text { protein } \\
(\mathrm{mg})\end{array}$ & $\begin{array}{l}\text { Specific activity } \\
\text { ( } \mu \text { mol/min per } \\
\mathrm{mg} \text { of protein) }\end{array}$ & $\begin{array}{c}\text { Total } \\
\text { activity } \\
(\mu \mathrm{mol} / \mathrm{min})\end{array}$ & $\begin{array}{l}\text { Yield of } \\
\text { activity } \\
(\%)\end{array}$ & $\begin{array}{l}\text { Purifi- } \\
\text { cation } \\
\text { (fold) }\end{array}$ \\
\hline $\begin{array}{l}\text { Homogenates after low-speed centrifugation } \\
53000 \mathrm{~g} \text { supernatant } \\
\left(\mathrm{NH}_{4}\right)_{2} \mathrm{SO}_{4} \text { fractionation }(40-50 \% \text { saturation }) \\
\text { Sepharose } 6 \mathrm{~B} \text { peak fraction } \\
\text { All fractions with activity }\end{array}$ & $\begin{array}{r}135.00 \\
15.20 \\
11.20 \\
0.80 \\
0.66\end{array}$ & $\begin{array}{r}5670 \\
502 \\
112 \\
2.4 \\
15.8\end{array}$ & $\begin{array}{l}0.003 \\
0.026 \\
0.086 \\
0.570 \\
0.290\end{array}$ & $\begin{array}{r}15.30 \\
13.04 \\
9.64 \\
1.37 \\
4.58\end{array}$ & $\begin{array}{r}100 \\
85 \\
63 \\
9 \\
30\end{array}$ & $\begin{array}{l}-7.7 \\
29 \\
190 \\
97\end{array}$ \\
\hline
\end{tabular}

\section{Results and Discussion}

\section{Enzyme purification}

The final procedure used for malate synthase purification had the advantage of simplicity combined with good yield (Table 1). An important step in the procedure was the use of dark-grown Euglena; the absence of chloroplast proteins facilitated purification and enhanced the amount of malate synthase in the cell. The molecular weight of the intact enzyme was such that Sepharose 6B gave a good separation from other cellular proteins remaining at that stage of purification. In contrast, attempts to purify the enzyme by centrifugation on linear sucrose gradients were unsuccessful, as the molecular weight of the enzyme was not great enough to facilitate separation from other proteins, as occurs with Euglena ribulose 1,5-bisphosphate carboxylase (Brown et al., 1976). Preparative polyacrylamide-gel electrophoresis gave a good separation of malate synthase from other proteins, but had the disadvantage of a major loss of enzymic activity. Inclusion of ion-exchange chromatography in the purification procedure was unnecessary; malate synthase failed to bind to either CM- or DEAE-cellulose at all stages of purification, indicating the absence of high ionic charge on the intact enzyme. After partial purification yeast malate synthase was contaminated with citrate synthase (Dixon et al., 1960), and as malate synthase is present with the glyoxylate-cycle enzymes in Euglena glyoxysomes (Collins \& Merrett, 1975b) possible contamination by these enzymes was investigated. However, assays for citrate synthase, malate dehydrogenase, aconitase or isocitrate lyase failed to show activity with purified Euglena malate synthase (Collins \& Merrett, 1975b). Some organelle proteins are glycoproteins (Campbell \& Blobel, 1976), but purified Euglena malate synthase did not give a positive reaction with the Schiff reagent when tested by the method of Segrest \& Jackson (1972).

\section{Molecular-weight determinations}

The whole enzyme was found to have a mol.wt. of about 350000 from its elution profile on the
Sepharose 6B column. For quaternary-structure determination SDS/polyacrylamide-gel electrophoresis was used. Attempts to dissociate the enzyme into its constituent subunits by using only SDS were unsuccessful, complete dissociation only being obtained when $1 \%$ SDS was used in conjunction with $8 \mathrm{M}$-urea. Peak fractions from the Sepharose 6B column treated in this way showed a single protein band. SDS/polyacrylamide-gel electrophoresis of the dissociated enzyme and comparison of electrophoretic mobility with protein monomers of known

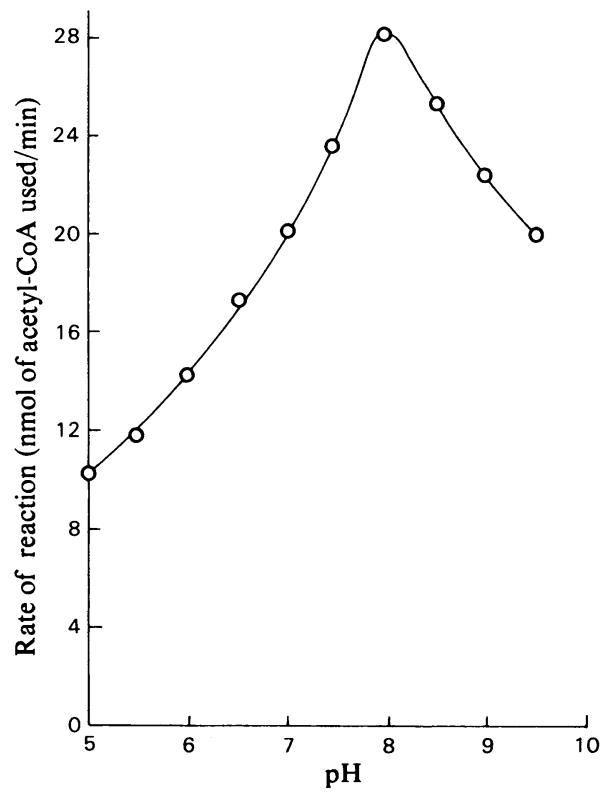

Fig. 1. Effect of $\mathrm{pH}$ on enzymic activity of malate synthase Standard assay conditions were used as described in the Materials and Methods section, except that Tris/HCl buffer was replaced by $33 \mathrm{~mm}$-Tes $(2-\{[2-$ hydroxy-1,1-bis(hydroxymethyl)ethyl]amino\}ethanesulphonic acid) over the $\mathrm{pH}$ range 5.0-7.0 and by $33 \mathrm{~mm}$-Hepes [4-(2-hydroxyethyl)-1-piperazineethanesulphonic acid] over the $\mathrm{pH}$ range 7.5-9.5. 

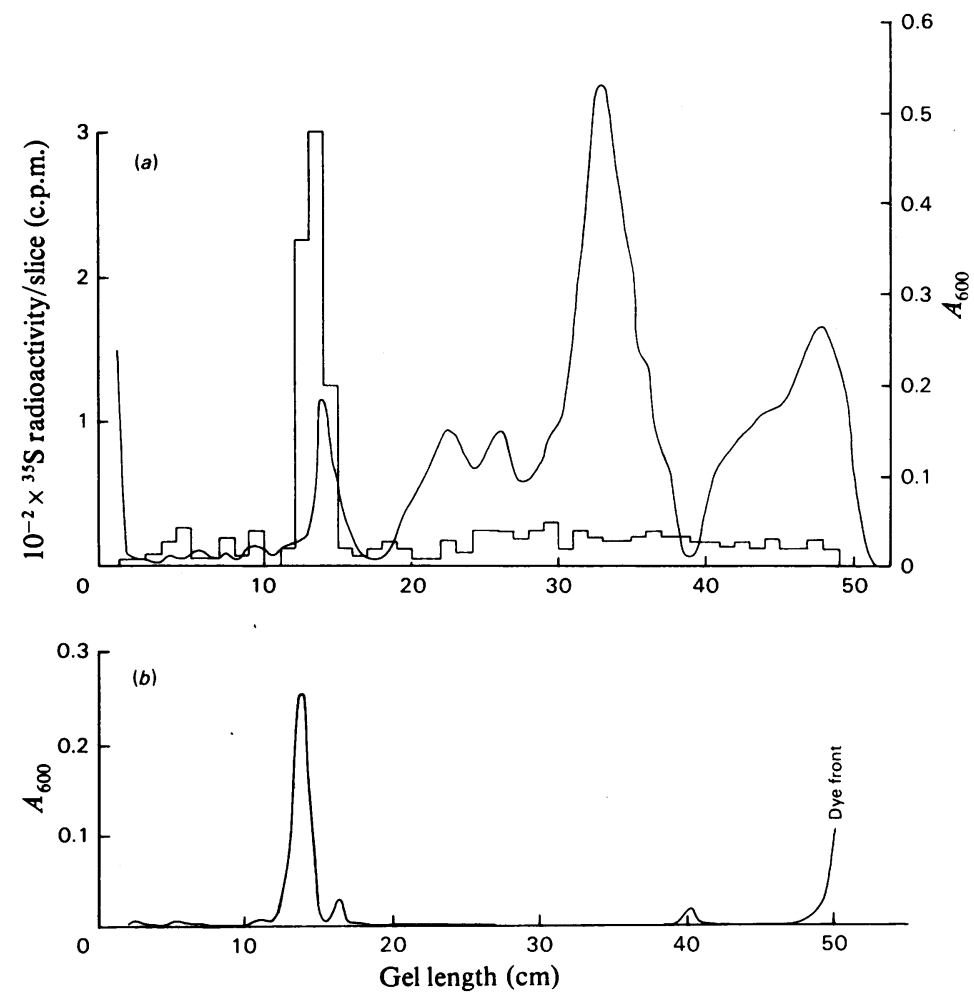

Fig. 2. Analysis of immunoprecipitate resulting from the reaction of anti-(malate synthase) with extract of ${ }^{35} S$-labelled cells by SDS/polyacrylamide-gel electrophoresis

Cells were labelled, disrupted, made to react with anti-(malate synthase) and immunoprecipitate was examined electrophoretically as described in the Materials and Methods section. (a) Densitometer trace of immunoprecipitate and histogram showing radioactivity of $1 \mathrm{~mm}$ gel slices; $(b)$ densitometer trace of pure enzyme for comparison.

molecular weight established the mol.wt. of the subunit as $\mathbf{1 7 5 0 0 0}$. This indicates that the whole enzyme is composed of two subunits.

\section{pH optimum and kinetic properties of purified enzyme}

The optimum pH for enzyme activity was 8.0 (Fig. 1), which differs from the value of 7.0 reported by Cook (1970) for the partially purified enzyme. The purified enzyme had a $K_{\mathrm{m}}$ for glyoxylate of $50 \mu \mathrm{M}$ and for acetyl-CoA of $80 \mu \mathrm{M}$. As reported previously for malate synthase from yeast (Dixon et al., 1960) and higher plants (Servettaz et al., 1973), glycollate was a potent competitive inhibitor of the enzyme, the $K_{\mathrm{m}}$ for glyoxylate increasing to $0.8 \mathrm{~mm}$ in the presence of $0.5 \mathrm{~mm}$-glycollate.

\section{Immunochemical studies}

Purified malate synthase gave a single sharp precipitin band on Ouchterlony double-diffusion gels against anti-(malate synthase), but gave no reaction with control (preimmunization) serum. The antiserum specifically precipitated malate synthase from a mixture of proteins (Fig. $2 a$ ). When anti-(malate synthase) was added to an extract of ${ }^{35} \mathrm{~S}$-labelled cells, analysis of the resultant immunoprecipitate by SDS/ polyacrylamide-gel electrophoresis produced a single peak of radioactive protein with mobility closely corresponding to that of the enzyme subunit (Fig. 2). Negligible radioactivity was precipitated by control serum. The two major non-radioactive protein peaks of the immunoprecipitate, with mol.wts. of approx. 30000 and 60000 , correspond to the light and heavy chains respectively of immunoglobulin G. These observations show that the antiserum is monospecific for malate synthase in Euglena cell extracts.

Reaction of anti-(malate synthase) with purified enzyme gave a good titre (Fig. 3) and measurement of catalytic activity demonstrated that the enzyme was completely immunoprecipitated (Fig. 4). 


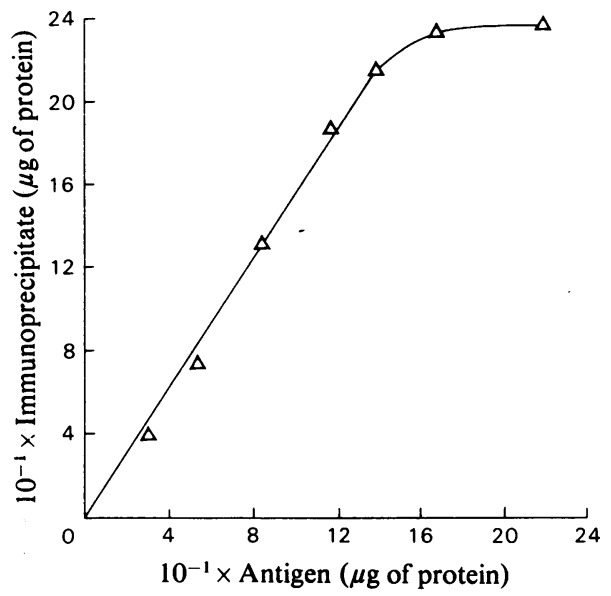

Fig. 3. Immunotitration of purified Euglena malate synthase Antiserum $(0.1 \mathrm{ml})$ was incubated with malate synthase in a volume of $0.6 \mathrm{ml}$ for $30 \mathrm{~min}$ at $37^{\circ} \mathrm{C}$ followed by storage at $4^{\circ} \mathrm{C}$ for $16 \mathrm{~h}$. Immunoprecipitates were collected, washed and protein determined as described in the Materials and Methods section.

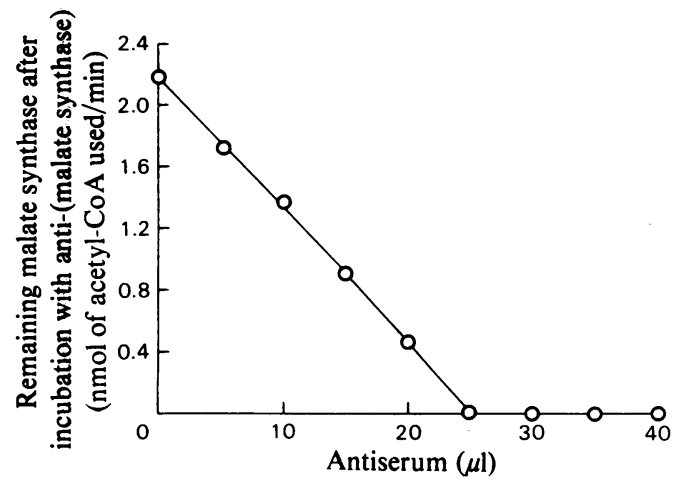

Fig. 4. Effect of malate synthase antiserum on enzyme activity

Samples $(50 \mu \mathrm{l})$ of malate synthase were incubated with increasing amounts of antiserum in a final volume of $150 \mu \mathrm{l}$ for $30 \mathrm{~min}$ at $37^{\circ} \mathrm{C}$ followed by $16 \mathrm{~h}$ at $4^{\circ} \mathrm{C}$. Immunoprecipitates were removed and remaining enzyme activity was determined as described in the Materials and Methods section.

The reaction of anti-(malate synthase) with extracts from cells grown phototrophically on $\mathrm{CO}_{2}$ and cells grown heterotrophically on acetate showed the presence of malate synthase protein only in the latter. Thus the development of malate synthase activity observed when acetate is added and cultures darkened (Woodward \& Merrett, 1975) results from the synthesis of enzyme protein rather than enzyme activation.
Euglena anti-(malate synthase) was tested by Ouchterlony double-diffusion gels against extracts from higher plants and micro-organisms grown on acetate as carbon source. A positive precipitin reaction was observed between the antiserum and extracts of acetate-grown $E$. coli, the presence of the precipitin band being confirmed by staining for protein with Coomassie Blue. Cells of Chlorella fusca grown heterotrophically on acetate contain malate synthase (Syrett et al., 1963; Goulding \& Merrett, 1966), but cell extracts failed to give a precipitin reaction with Euglena anti-(malate synthase). During the germination of the fat-storing seed the glyoxylate cycle functions in the conversion of fat into carbohydrate, but cell extracts of Zea mays scutella and malate synthase from Ricinus communis cotyledons failed to give a positive reaction with Euglena anti-(malate synthase). Thus, although Euglena malate synthase is immunologically related to the $E$. coli enzyme there is no immunological correspondence between this enzyme and malate synthase from Chlorella or higher plants. This lack of immunological correspondence may reflect the difference in quaternary structure between the Euglen $a$ and the higher-plant malate synthase. Recent work has shown that malate synthase from cucumber cotyledons has a mol.wt. of 590000 , with a subunit mol.wt. of 63000 (Köller \& Kindl, 1977), and malate synthase from Ricinus communis cotyledons has a mol.wt. of 575000 (Bowden \& Lord, 1978).

\section{References}

Andrews, P. (1965) Biochem. J. 96, 595-606

Bowden, L. \& Lord, J. M. (1978) Plant Physiol. 61, 259-265

Bray, G. A. (1960) Anal. Biochem. 1, 279-285

Brown, R. H., Armitage, T. L. \& Merrett, M. J. (1976) Plant Physiol. 58, 773-776

Campbell, P. N. \& Blobel, G. (1976) FEBS Lett. 72, 215-226

Collins, N. \& Merrett, M. J. (1975a) Biochem. J. 148, 321-328

Collins, N. \& Merrett, M. J. (1975b) Plant Physiol. 55, 1018-1022

Cook, J. R. (1970) J. Protozool. 17, 232-235

Cramer, M. \& Myers, J. (1952) Arch. Mikrobiol. 17, 384-402

Dawson, R. M. C., Elliott, D. C., Elliott, W. H. \& Jones, K. M. (eds.) (1969) Data for Biochemical Research, Oxford University Press, London

Dixon, G. H., Kornberg, H. L. \& Lund, P. (1960) Biochim. Biophys. Acta 41, 217-233

Duntze, W., Neumann, D., Gancedo, J. M., Atzpodien, W. \& Holzer, H. (1969) Eur. J. Biochem. 10, 83-89

Falmagre, P., Vanderwinkel, E. \& Wiame, J. M. (1965) Biochim. Biophys. Acta 99, 246-258

Goulding, K. H. \& Merrett, M. J. (1966) J. Exp. Bot. 17, 678-689

Harrop, L. C. \& Kornberg, H. L. (1966) Proc. R. Soc. London Ser. B 166, 11-29 
Hogg, J. F. \& Kornberg, H. L. (1963) Biochem. J. 86, 462-468

Kabat, E. A. \& Mayer, M. M. (1961) Kabat and Mayer's Experimental Immunochemistry, C. C. Thomas, Springfield

Köller, W. \& Kindl, H. (1977) Arch. Biochem. Biophys. 181, 236-248

Kornberg, H. L. (1959) Annu. Rev. Microbiol. 13, 49-78

Lowry, O. H., Rosebrough, N. J., Farr, A. L. \& Randall, R. J. (1951) J. Biol. Chem. 193, 265-275

Ouchterlony, Ö. (1968) Handbook of Immuno-diffusion and Immuno-electrophoresis, Ann Arbor Science Publishers, Ann Arbor
Segrest, J. P. \& Jackson, R. L. (1972) Methods Enzymol. 28, 54-63

Servettaz, O., Filippini, M. \& Longo, C. P. (1973) Plant Sci. Lett. 1, 71-80

Syrett, P. J., Merrett, M. J. \& Bocks, S. M. (1963) J. Exp. Bot. 14, 249-264

Weber, K. \& Osborn, M. (1969) J. Biol. Chem. 244, 4406-4412

Weitzman, P. D. J. (1969) Methods Enzymol. 13, 22-26

Wong, D. T. O. \& Ajl, S. J. (1956) J. Am. Chem. Soc. 78, 3230-3231

Woodward, J. \& Merrett, M. J. (1975) Eur. J. Biochem. $55,555-559$ 